$\triangle$ CTA $\mathbb{N E O P H I L O L O G I C A}$

UDK: 821.111(73).09-31Auster P.:

DOI: 10.4312/an.52.1-2.199-214 821.133.1-94Chateaubriand F.-R. de

\title{
Traduire Chateaubriand dans le Vermont: les Mémoires d'Outre-Tombe dans Le livre des illusions de Paul Auster
}

\section{Katarina Marinčič}

\section{Résumé}

Cet article présente une analyse des rapports intertextuels entre le roman Le livre des illusions (The Book of Illusions) de Paul Auster et les Mémoires d'Outre-Tombe de François-René de Chateaubriand. Le protagoniste-narrateur du roman, bouleversé par une tragédie personnelle, recouvre une raison de vivre dans la tâche quasi impossible de faire une traduction intégrale des Mémoires d'Outre-Tombe. Au cours de l'histoire racontée dans le roman, l'immensité de ce travail entre au second plan. Initialement ressentie comme « un tas de charbon à pelleter ", l'autobiographie de Chateaubriand devient un modèle à suivre au niveau formel aussi bien qu'au niveau moral. L'ambition de parler de l'au-delà s'impose à la fois comme l'objectif de vie du protagoniste et comme le squelette narratif du roman.

Mots-clés: Paul Auster, François René de Chateaubriand, intertextualité, traduction, autobiographie 


\section{DAVID ZIMMER ET SES DEUX ANGES SAUVEURS}

Bien qu'intitulé Le livre des illusions (The Book of Illusions), le dixième roman de Paul Auster, publié en 2002, se présente avant tout comme un livre sur le deuil. L'histoire primaire, qui constitue le cadre narratif du roman, est celle d'un homme frappé par la plus grande tragédie imaginable, la mort soudaine de ses proches. Après avoir perdu son épouse et ses deux fils dans un accident d'avion, David Zimmer, professeur de littérature, quadragénaire, continue à vivre sans raison de vivre, se noyant dans une stupeur continue, $s$ 'isolant de plus en plus, passant ses soirées à boire et à regarder la télévision. Son premier ange sauveur lui apparaît au cours d'une telle soirée. Un extrait d'un vieux film muet le fait rire pour la première fois depuis la disparition de sa famille.

That was how things stood for me when Hector Mann unexpectedly walked into my life. I had no idea who he was, had never even stumbled across a reference to his name, but one night just before the start of winter, when the trees had finally gone bare and the first snow was threatening to fall, I happened to see a clip from one of his old films on television, and it made me laugh. That might not sound important, but it was the first time I had laughed at anything since June, and when I felt that unexpected spasm rise up through my chest and begin to rattle around in my lungs, I understood that I hadn't hit bottom yet, that there was still some piece of me that wanted to go on living. (Auster 9)

Le comédien appelé Hector Mann, lui aussi personnage fictif, sera le deuxième héros du livre, le protagoniste de l'histoire encadrée par le récit à la première personne de Zimmer. C'est donc Zimmer qui nous racontera la vie tourmentée de Mann : il le fera avec une empathie hors du commun, surprenante de la part de quelqu'un qui est en train de reconstruire sa propre existence.

Avant de se plonger dans le destin de l'homme, Zimmer se consacre à l'étude de son œuvre :

I wrote the book because I wanted to share my enthusiasm for Hector's work. The story of his life was secondary to me, and rather than speculate on what might or might not have happened to him, I stuck to a close reading of the films themselves. (ibid. 3)

Il le fait par reconnaissance, pour payer sa dette envers l'artiste qui lui avait rendu la capacité de rire, mais aussi pour passer le temps, pour se donner une raison de se lever le matin. Après la publication de sa monographie sur Hector Mann (intitulée Le Monde silencieux d'Hector Mann, The Silent World of Hector Mann), Zimmer retombe dans la léthargie.

Il fait un séjour prolongé à New York, puis retourne dans le Vermont où il avait 
vécu avec sa famille. Au lieu de retourner dans leur ancienne maison, il s'installe dans un bungalow sans caractère qui lui convient parce qu'il est vide de souvenirs. De nouveau, il sombre dans le désespoir.

L'ange qui vient à son secours cette fois n'est pas un personnage inventé. I1 s'appelle François René de Chateaubriand. Selon Zimmer, il est l'auteur de la meilleure autobiographie jamais écrite (Auster-Le Bœuf 72), the best autobiography ever written (Auster 60).

En effet, l'apparition de Chateaubriand dans la vie de Zimmer, quoique littéralement une apparition d'outre-tombe, n'est pas si miraculeuse que celle de Mann. Devenu superstitieux dans son isolement, le professeur Zimmer incline à voir partout des signes.

In the past, I had never been one to believe in mystical claptrap of that sort. But when you live as I was living then, all shut up inside yourself and not bothering to look at anything around you, your perspective begins to change. For the fact was that Alex's letter was dated Monday the ninth, and I had received it on Thursday the twelfth, three days later. Which meant that when he was in New York writing to me about the book, I had been in Vermont holding the book in my hands. I don't want to insist on the importance of the connection, but I couldn't help reading it as a sign. It was as if I had asked for something without knowing it, and then suddenly my wish had been granted. (ibid. 69)

Or, les coïncidences qui l'amènent à Chateaubriand (ou plutôt : qui lui amènent Chateaubriand) sont beaucoup moins étranges que les hasards qui vont, bientôt, le replonger dans le monde - pas tellement silencieux cette fois - d'Hector Mann. Après tout, Zimmer est un expert en littérature française du XIXe siècle : avant la perte tragique de sa famille il était en train de commencer une étude sur Stendhal. Quand un collègue universitaire lui écrit pour demander s'il serait intéressé de faire une nouvelle traduction intégrale des Mémoires d'Outre-Tombe, cette proposition est doublement motivée : le collègue cherche un bon traducteur pour le grand livre, mais aussi et surtout une grande tâche pour Zimmer, quelque chose qui va le tirer de sa léthargie et l'occuper pour longtemps.

Il accepte et se met au travail, oubliant son premier ange sauveur.

So I settled down and began working again. I forgot about Hector Mann and thought only about Chateaubriand, burying myself in the massive chronicle of a life that had nothing to do with my life. (ibid. 69-70)

Son admiration, voire sa ferveur pour Chateaubriand est évidente. En témoigne la traduction d'un des extraits les plus anthologiques des Mémoires d'Outre-Tombe, incrustée dans la narration de Zimmer et commentée par celui-ci. 
Un poète breton, nouvellement débarqué, m'avait prié de le mener à Versailles. Il y a des gens qui visitent des jardins et des jets d'eau, au milieu du renversement des empires : les barbouilleurs de papier ont surtout cette faculté de s'abstraire dans leur manie pendant les plus grands événements ; leur phrase ou leur strophe leur tient lieu de tout.

Je menai mon Pindare à l'heure de la messe dans la galerie de Versailles. L'Oeil-de-Bœuf était rayonnant : le renvoi de M. Necker avait exalté les esprits. On se croyait sûr de la victoire : peut-être Sanson et Simon mêlés dans la foule, étaient spectateurs des joies de la famille royale.

La Reine passa avec ses deux enfants ; leur chevelure blonde semblait attendre des couronnes : madame la duchesse d'Angoulême âgée de onze ans, attirait les yeux par un orgueil virginal ; belle de la noblesse du rang et de l'innocence de la jeune fille, elle semblait dire comme la fleur d'oranger de Corneille, dans la Guirlande de Julie :

"J'ai la pompe de ma naissance.»

Le petit Dauphin marchait sous la protection de sa sœur, et M. Du Touchet suivait son élève. Il m'aperçut et me montra obligeamment à la Reine. Elle me fit en me jetant un regard avec un sourire, ce salut gracieux quelle m'avait déjà fait le jour de ma présentation. Je n'oublierai jamais ce regard qui devait s'éteindre sitôt. Marie-Antoinette, en souriant, dessina si bien la forme de sa bouche, que le souvenir de ce sourire (chose effroyable) me fit reconnaître la mâchoire de la fille des rois, quand on découvrit la tête de l'infortunée dans les exhumations de 1815. (Chateaubriand 1951:167)

The first thing my eyes had fallen upon was a short passage in volume one. In it, Chateaubriand tells of accompanying a Breton poet on an outing to Versailles in June of 1789. It was less than a month before the taking of the Bastille, and halfway through their visit they spotted Marie Antoinette walking by with her two children. Casting a smiling look in my direction, she gave me the same gracious salute that I had received from her on the day of my presentation. I shall never forget that look of hers, which was soon to be no more. When Marie-Antoinette smiled, the shape of her mouth was so clear that (horrible thought!) the memory of that smile enabled me to recognize the jaw of this daughter of kings when the head of the unfortunate woman was discovered in the exhumations of 1815. It was a fierce, breathtaking image, and I kept thinking about it long after I had closed the book and put it on the shelf. Marie-Antoinette's severed head, unearthed from a pit of human remains. In three short sentences, Chateaubriand travels twenty-six years. He goes from flesh to bone, from piquant life to anonymous death, and in the chasm between them lies the experience of an entire generation, the unspoken years of terror, brutality, and madness. I was stunned by the passage, moved by it in a way that no words had moved me in a year and a half. (Auster 68-69) 
Hector Mann avait rendu à Zimmer la capacité de rire, Chateaubriand lui rend la capacité de s'émouvoir et, last but not least, celle de s'enthousiasmer pour le travail d'un grand styliste. Grâce à Chateaubriand, Zimmer redécouvre la littérature.

\section{IT'S HIGH TIME SOMEONE DID ANOTHER}

Pourquoi un expert américain en littérature française se déciderait-il à faire, à la fin des années 80 du XXe siècle, une nouvelle traduction intégrale des Mémoires d'outre-tombe? À part son admiration pour l'écrivain, il y a une raison concrète, voire banale derrière la décision de Zimmer. Pour citer le collègue universitaire : il est temps que quelqu'un entreprenne cette tâche.

»This, « you said (holding up the first volume of the French edition and waving it in the air), »is the best autobiography ever written." I don't know if you still feel that way now, but I probably don't have to tell you that there have been only two complete translations since the book was published in 1848. One in 1849 and one in 1902. It's high time someone did another, don't you think? (ibid. 60)

A vrai dire, au moment où David Zimmer se met au travail, il n'existe qu'une seule traduction intégrale en anglais, celle d'Alexander Teixieira de Mattos, publiée en 1902. La traduction anonyme publiée en 1849 (et mentionnée par l'ami de Zimmer) s'arrête au début du treizième livre des Mémoires.

Néanmoins, au temps où Zimmer relit et traduit l'extrait sur Marie-Antoinette, le lecteur anglophone peut déjà choisir entre trois versions de cette page anthologique. Détail surprenant : le traducteur anonyme de 1849 est le seul parmi les traducteurs anglo-américains de Chateaubriand à prendre soin d'éviter le mot woman pour parler de la reine de France.

The Queen passed, accompanied by her two children; their fair silken locks seemed awaiting a crown; the Duchesse d'Angoulême, then eleven years old, attracted all eyes by the modest dignity of her mien; beautiful in her exalted rank and in her maiden innocence, she seemed to say, like the orange blossom in Corneille's Guirlande de Julie:

"J'ai la pompe de ma naissance.»

The little dauphin walked under the protection of his sister, and M. du Touchet followed his pupil; this gentleman saw me, and obligingly pointed me out to the queen. She smiled, and saluted me in the same gracious way as she had done on the day of my presentation. - I shall never forget that glance, so soon to be extinguished in death. When she smiled, Marie-Antoinette showed the form of her mouth so clearly, that the remembrance of that smile (fearful idea!) 
enabled me to recognize the jaw, when the head of this unfortunate daughter of kings was discovered during the exhumations in 1815 (Chateaubriand 1849: 207).

Zimmer (ou bien Paul Auster) traduit l'adjectif substantivé l'infortunée (employé par Chateaubriand) comme the unfortunate woman, Teixieira de Mattos comme the unhappy woman:

The Queen passed by with her two children; their fair hair appeared to be waiting for crowns: Madame la Duchesse d'Angoulême, aged eleven, drew all eyes through a virginal pride; beautiful through nobility of birth and maidenly innocence, she seemed to say, like Corneille's orange-blossom in the Guirlande de Julie:

"J'ai la pompe de ma naissance.»

The little Dauphin walked under his sister's protection, and M. du Touchet followed his pupil; he noticed me, and obligingly called the Queen's attention to me. Casting a smiling look in my direction, she gave me that gracious bow which she had already made me on the day of my presentation, I shall never forget that look, so soon to be extinguished. Marie Antoinette, when she smiled, outlined so clearly the shape of her mouth, that the recollection of that smile (O horror!) enabled me to recognize the jaw-bone of the daughter of kings when the head of the unhappy woman was discovered in the exhumations of 1815. (Chateaubriand 1902: 206-207)

Robert Baldick (sa traduction abrégée est publiée en 1961 et réimprimée en 1972 dans la collection Penguin Books) opte lui aussi pour the unfortunate woman. La version de Baldick se distingue des autres par un rythme plus vivace - ou bien par un ton moins élégiaque. Parmi les traducteurs cités, Baldick est le seul à omettre le vers de la Guirlande de Julie, évitant ainsi le besoin de faire une note explicative qui ralentirait le récit.

The Queen passed by with her two children; their fair hair seemed to be waiting for crowns. Mme la Duchesse d'Angoulême, aged eleven, drew all eyes by her virginal dignity. The little Dauphin walked under his sister's protection, and M. Du Touchet followed his pupil; he noticed me and obligingly pointed me out to the Queen. Casting a smiling glance in my direction, she made the same gracious bow to me which she had given me on the day of my presentation. I shall never forget that look of hers which was so soon to be extinguished. Marie Antoinette, when she smiled, shaped her lips so clearly that, horrible to relate, the recollection of that smile enabled me to recognize the jaw-bone of the daughter of kings when the head of the unfortunate woman was discovered in the exhumations of 1815. (Chateaubriand 1972: 134-135) 


\section{UN MILLION DE MOTS}

En traduisant Les Mémoires d'Outre-Tombe, Zimmer fait quelque chose de nécessaire et d'intellectuellement gratifiant. Du point de vue intime, pourtant, le plus grand attrait que le livre présente pour lui semble être sa longueur. L'énormité du travail auquel il se livre lui apporte une satisfaction presque physique.

Much of the work was mechanical, and because I was the servant of the text and not its creator, it demanded a different kind of energy from the one I had put into writing The Silent World. Translation is a bit like shovelling coal. You scoop it up and toss it into the furnace. Each lump is a word, and each shovelful is another sentence, and if your back is strong enough and you have the stamina to keep at it for eight or ten hours at a stretch, you can keep the fire hot. With close to a million words in front of me, I was prepared to work as long and as hard as necessary, even if it meant burning down the house. (Auster 70)

Aussi long et aussi dur qu'il le faudrait, même si cela impliquait l'incendie de la maison (Auster-Le Bœuf 83). Le traducteur doit-il vraiment incendier la maison (ou presque) dans l'effort de traduire un livre de trois mille pages? Alexander Teixieira de Mattos, tout en insistant sur l'énormité de la tâche, s'exprime d'une façon moins dramatique :

/.../ I have striven to perform my task of translation, which has taken me over two years to accomplish, conscientiously, correctly, and above all respectfully. If here and there I have seemed to follow the original a little to closely, my excuse must be that I hat too great a respect for this great man to take liberties with his writing. To reproduce his style in another language has been no easy matter: I have done my best. (Chateaubriand 1902: 103)

Seize ans après la parution du roman d'Auster (et presque trente ans après l'aventure de traduction dans la vie fictive de David Zimmer), Alex Andriesse publie une nouvelle version anglaise des douze premiers livres des Mémoires d'OutreTombe. Dans son avant-propos, il souligne l'importance du canon littéraire personnel de Chateaubriand. Chateaubriand, constate Andriesse, est un auteur imprégné de tradition littéraire; d'autre part, il est un écrivain innovateur et influent; son traducteur est par conséquent obligé de procéder en historien de la littérature. Toutefois ce travail d'érudit n'est qu'un jeu d'enfant en comparaison avec l'effort nécessaire pour recréer la beauté stylistique de l'original. Selon Andriesse, les difficultés rencontrées par le traducteur des Mémoires s'expliquent par la qualité plutôt que par la quantité du texte français.

Although this is not a complete edition of the Memoirs, it does reproduce the first of the work's four parts, including the oft-omitted chapter headings 
and detailed dates of composition. As for the translation, it is, I recognize, imperfect and provisional-a failure in a sense. However, as I failed, I tried always to bear in mind that the work I was wrenching into English was the work of a writer steeped in literary tradition. I hope that this is reflected in the prose itself, but it is on deliberate display in the notes at Chateaubriand's personal canon. /.../ Compiling notes is child's play, though, in comparison with trying to capture some reverberation of Chateaubriand's style in English. (Chateaubriand 2018: 16)

La version la plus récente de l'extrait anthologique admiré et traduit par David Zimmer (ou bien par Paul Auster) ne s'éloigne pas beaucoup des précédentes sauf pour un détail. Le salut gracieux de Marie Antoinette - salut de la reine de France à un gentilhomme breton de 21 ans - devient, chez Andriesse, « a curtsy ».

The Queen passed by with her two children. Their blond heads seemed to be awaiting their crowns. The eleven-year-old Madame le Duchesse d'Angoulême, in particular, attracted all eyes with her virginal dignity. Beautiful by dint of her noble blood and her girlish innocence, she seemed to say, like Corneille's orange flower in the Guirlande de Julie:

"I have all the splendour of my birth."

The little Dauphin walked under his sister's guidance, and M. Du Touchet followed close behind his pupil. He noticed me and obligingly pointed me out to the Queen. Casting her eyes on me with a smile, she made me the same charming curtsy as she had on the day of my presentation. I will never forget those eyes, which were so soon to be extinguished. When Marie-Antoinette smiled, the shape of her mouth was so clear that the memory of this smile (horrible thought!) allowed me to recognize the jaw of this daughter of kings when the unfortunate woman's head was discovered in the exhumations of 1815. (ibid. 203)

\section{UN CONTEMPORAIN DE ZIMMER}

Jusqu'à l'époque où se déroule le roman de Paul Auster, et bien au delà, l'histoire des traductions anglaises des Mémoires d'Outre-Tombe semble donc présenter une série d'échecs plus ou moins avoués, plus ou moins pénibles. Grâce à ses propres expériences de traducteur (cf. Brown 11; Hutchisson XVI; Varvogli 59; Donovan 183; Barone 21), Paul Auster est tout à fait en état de comprendre de tels échecs et l'humiliation qu'ils apportent. Des traductions intégrales " qui s'arrêtent à un tiers du livre, des abrégés, des " nouvelles éditions " qui ne sont, en vérité, que des reprints (ainsi l'édition Penguin Classics de la traduction de R. Baldick), les traducteurs qui, dans les avant-propos, s'attardent sur les difficultés rencontrées 
pendant leur long travail - tout cela nous amène presque à croire (dans l'esprit superstitieux de David Zimmer) à une malédiction frappant les admirateurs anglais et américains de Chateaubriand.

Pour le dire plus sobrement, on arriverait presque à considérer Les Mémoires d'Outre-Tombe comme un texte intraduisible en anglais - si ce nétait pour A.S. Kline.

En 2005, à peine trois ans après la parution du Livore des illusions, une traduction intégrale des Mémoires d'Outre-Tombe est mise en ligne en accès libre par ce traducteur britannique, homme de lettres exceptionnel ainsi qu'exceptionnellement généreux.

Né en 1947,A.S. Kline est contemporain de David Zimmer - et il a exactement le même âge que Paul Auster. (Est-ce une coïncidence? Probablement, mais on ne peut pas nier que c'est une coïncidence profondément ironique.) Mathématicien de formation, Kline se décide, après une carrière d'informaticien, de se consacrer entièrement à la littérature. On lui doit entre autre une traduction en anglais des Métamorphoses d'Ovide, une traduction de la Comédie divine, une traduction de l'œuvre complète de Chrétien de Troyes, une traduction des Lais de Marie de France ... En juin 2019, l'annonce suivante apparait sur son site internet Poetry in Translation (https://www.poetryintranslation.com) :

I am in the last stages of work on Guillaume de Lorris: "Le Roman de la Rose« Written c1230, in 4000 or so lines of Middle French, the Romance of the Rose is an allegorical work on the subject of love, and a fascinating development of the courtly tradition. I am translating in the octosyllabic verse couplets of the original text. In have reconsidered Jean de Meung's Continuation of this work and can now see the seeds of his more satirical approach in Guillaume's sophisticated original. I shall be translating the 17000 line Continuation next.

Pour employer un understatement digne d'A.S. Kline : Chateaubriand n'est pas le seul grand auteur (ni le seul auteur prolifique) qu'il traduit. Conformément à cela, son avant-propos aux Mémoires d'Outre-Tombe est sobre et non prétentieux.

Once encountered Chateaubriand is unforgettable, and the Memoirs deserve much wider literary and historical recognition. They have suffered from an unmerited neglect, due to their extent, and the previous lack of a complete English translation, a lack which is here remedied, the work being further enriched by over six hundred illustrations, and a fully detailed index. (Chateaubriand 2005:5)

Un coup du destin digne d'un roman de Paul Auster : ce qui paraît presque impossible dans le monde fictif - comme par exemple de faire une traduction intégrale des Mémoires d'Outre-Tombe - devient, grâce à un personnage extraordinaire, tout à fait possible dans le monde réel. 


\section{CHATEAUBRIAND OU MANN}

Un après-midi humide et venteux du début de l'été, le traducteur Zimmer, pleinement occupé à compter les pages de la meilleure autobiographie jamais écrite, reçoit une lettre d'une inconnue.

I was almost a hundred pages into the Chateaubriand translation at that point, and when The Silent World of Hector Mann was released a year later, I had another twelve hundred pages behind me. If I kept working at that pace, I would have a completed draft in seven or eight more months. Add on some extra time for revisions and changes of heart, and in less than a year I would be delivering a finished manuscript to Alex.

As it turned out, that year lasted only three months. I pushed on for another two hundred fifty pages, reaching the chapter about the fall of Napoleon in the twenty-third book (miseries and wonders are twins, they are born together), and then, one damp and blustery afternoon at the beginning of summer, I found Frieda Spelling's letter in my mailbox. (Auster 77)

Frieda Spelling prétend être l'épouse d'Hector Mann. Elle remercie Zimmer pour son livre, l'informe que l'acteur, mystérieusement disparu en 1929, est toujours vivant, quoique de santé fragile, et l'invite de leur rendre visite au Nouveau Mexique où ils habitent depuis des années. Zimmer ne lui répond pas. Intrigué mais incrédule, il n'a aucune intention de faire le long voyage qu'elle lui propose. Peu importe, il y est emmené en personne par une jeune amie du couple qui vient le chercher dans le Vermont.

Avec cette jeune femme, qui s'appelle Alma, Zimmer retrouve l'amour. En faisant la connaissance d'Hector Mann, en apprenant son histoire personnelle, il découvre l'homme derrière l'œuvre. Seulement pour découvrir, derrière l'homme, comme dans une série de mises en abyme, toute une autre œuvre cinématographique, auparavant inconnue, inextricablement liée au destin de son créateur.

Inutile à dire, Zimmer finit par perdre les deux, le nouvel amour et, dans la même suite d'événements catastrophique, tous les films que Mann avait fait après sa mystérieuse disparition. L'héritage artistique d'Hector Mann est détruit par Frieda Spelling, suivant la volonté testamentaire du cinéaste. Alma se suicide après avoir accidentellement tué la veuve d'Hector.

Chateaubriand est-il oublié dans tout ce tumulte? Oui et non. Dans les circonstances changées, avec le nouvel espoir apporté par le nouvel amour, l'énormité du travail perd une grande partie de l'importance qu'elle avait pour Zimmer. S'il se réclame du million de mots des Mémoires d'Outre-Tombe, c'est pour rassurer son amoureuse : traduire l'autobiographie de Chateaubriand prend presque autant de temps qu'écrire la biographie d'Hector Mann (travail auquel la jeune femme se 
consacre avec passion depuis des années) : „I'll work on my Chateaubriand, you'll work on your biography, and when we aren't working, we'll fuck.» (Auster 290)

Par une logique profonde pourtant, les Mémoires d'Outre-Tombe, tout en devenant un souci secondaire pour David Zimmer, obtiennent finalement une place organique dans la structure du roman. Ce n'est plus la quantité qui importe, c'est la qualité particulière du texte et, last but not least, Chateaubriand lui-même avec son attitude envers le destin.

$\mathrm{Au}$ moment de leur première rencontre, Hector Mann donne à Zimmer une impression d'étrangeté : non pas parce qu'il est en train de mourir, mais, au contraire, parce qu'il est vivant, réel, parce qu'il est quelqu'un d'authentique (AusterLe Bœuf 254).

Until I saw him lying there in the bed, I'm not sure that I ever fully believed in him. Not as an authentic person, at any rate, not in the way I believed in Alma or myself, not in the way I believed in Helen or even Chateaubriand. (Auster 222)

Grâce à Alma, Zimmer obtient l'accès à la bibliothèque personnelle de l'acteur. Ce n'est qu'en découvrant les goûts littéraires de Mann que Zimmer reconnaît vraiment l'existence de celui-ci. En tant que lecteur, Hector Mann est son semblable, presque son frère.

I was about to pick it up to see where he had left off, but Alma took my hand again and led me over to the shelves in the back corner of the room. I think you'll find this interesting, she said. She pointed to a row of books several inches above her head (but exactly at my eye level), and I saw that all of them had been written by French authors: Baudelaire, Balzac, Proust, La Fontaine. A little to the left, Alma said, and as I moved my eyes to the left, scanning the spines for whatever it was she wanted to show me, I suddenly spotted the familiar green and gold of the two-volume Pléiade edition of Chateaubriand's Mémoires d'outre-tombe.

It shouldn't have made any difference to me, but it did. Chateaubriand wasn't an obscure writer, but it moved me to know that Hector had read the book, that he had entered the same labyrinth of memories that I had been wandering in for the past eighteen months. It was another point of contact, somehow, another link in the chain of accidental encounters and curious sympathies that had drawn me to him from the beginning. (ibid. 237-238)

A première vue, il ne s'agit ici que d'une simple manœuvre narrative : pour prouver qu'il n'a pas été abandonné quelque part en chemin vers le NouveauMexique, Chateaubriand obtient un rôle dans les vies entremêlées des deux protagonistes du roman. 


\section{DU DEUIL À LA RÉSIGNATION, DE LA RÉSIGNATION AU REFUS DE SE TAIRE}

Mais encore une fois, pourquoi Chateaubriand?

A part leurs goûts littéraires, Zimmer et Hector Mann partagent l'expérience du deuil. Plus spécifiquement, ils sont tous les deux pères endeuillés. Seraientils attirés par le désespoir de Chateaubriand, par la morosité qui se dégage son écriture?

Despair gave Zimmer's work an authenticity tenure couldn't. Now he is working on a new translation of the famously morose Chateaubriand's »Mémoirs d'outre-tombe« $[\mathrm{sic}]$.

Ainsi D.T.Max, le critique du New York Times, dans son analyse prudemment admirative du roman, publiée le 2 septembre 2002.

La vie de Chateaubriand, et par conséquent son autobiographie, est certainement marquée par la perte. Néanmoins, on peut trouver dans la littérature française (pour laquelle Zimmer et Mann ont une admiration commune) des livres qui parlent du deuil d'une manière plus directe, plus poignante. Tel par exemple le recueil fragmentaire Pour un Tombeau d'Anatole de Stéphane Mallarmé, écrit en 1879 et publié pour la première fois en 1961. Ce texte, le romancier Paul Auster le connaît bien. En effet, il est le premier à le traduire en anglais. (Sa traduction paraît en 1983 sous le titre A Tomb for Anatole; celle de Patrick McGuinness For Anatole's Tomb, en 2003).

La différence ne pourrait être plus apparente. Du côté de Mallarmé, même pas un cri de désespoir, juste quelques fragments des cris. Du côté de Chateaubriand, un monument littéraire érigé au cours d'un long goodbye solennel, voire pathétique.

Une petite remarque. L'humour de Chateaubriand n'est pas, semble-t-il, tellement appréciée par Zimmer, bien qu'il s'attarde sur l'ironie de sa longévité :

In effect, Chateaubriand mortgaged his autobiography to finance his old age. They gave him a nice chunk of money up front, which allowed him to pay off his creditors, and a guaranteed annuity for the rest of his life. It was a brilliant arrangement. The only problem was that Chateaubriand kept on living. The company was formed when he was in his mid-sixties, and he hung on until he was eighty. By then, the shares had changed hands several times, and the friends and admirers who had invested in the beginning were long gone. /.../

What a cheerful story.

Not so funny, I suppose, but let me tell you, the old viscount could write one hell of a good sentence. (Auster 63) 
Il y a, pourtant, une conviction que Mallarmé et Chateaubriand expriment tous les deux, et cette conviction est peut-être le lien le plus fondamental entre l'histoire de Zimmer et le destin d'Hector Mann : on peut mourir tout en continuant à vivre, on peut vivre et être mort tout ensemble. Pour citer la phrase poignante de Mallarmé, tirée d'une lettre qu'il écrit peu après la mort de son fils Anatole : "Tout ce que par contrecoup, mon être a souffert, pendant cette longue agonie, est inénarrable, mais heureusement je suis parfaitement mort. » (cit. Laufer 97).

Ce n'est pas par coïncidence que Zimmer radicalise le titre de l'autobiographie de Chateaubriand, en traduisant Mémoires d'Outre-Tombe comme Memoirs of a Dead Man : pas seulement que Chateaubriand parle (ou bien parlera) de l'au-delà à son futur lecteur, il se sent déjà mort au moment d'écrire l'histoire de sa vie.

Ce sentiment lugubre n'est pas sans une certaine douceur. Dans sa résignation finale, Hector Mann, comme Chateaubriand avant lui, cultive la compagnie des arbres :

In the darkness behind the main house, I could dimly make out the contours of Hector's trees-great hulks of shadow stirring in the wind.

Memoirs of a Dead Man opens with a passage about trees. I found myself thinking about that as we approached the front door, trying to remember my translation of the third paragraph of Chateaubriand's two-thousand-page book, the one that begins with the words Ce lieu me plait; il a remplacé pour moi les champs paternels and concludes with the following sentences: I am attached to my trees. I have addressed elegies, sonnets, and odes to them. There is not one amongst them that I have not tended with my own hands, that I have not freed from the worm that had attacked its root or the caterpillar that had clung to its leaves. I know them all by their names, as if they were my children. They are my family. I have no other, and I hope to be near them when I die. (Auster 220)

"Je cherche dans le mouvement de la forêt, dans le bruit des pins, quelquesuns des accents de la langue éternelle, » écrit Senancour, un autre mort-vivant (Senancour 227). David Zimmer, lui, n'est pas parmi ceux qui se consolent dans la nature. Son romantisme est d'une autre trempe. L'éternité qu'il trouve dans les Mémoires d'Outre-Tombe est une éternité à la mesure d'un homme superstitieux : une éternité basée sur la répétition. Tout dans la vie, même la mort, nous arrive plusieurs fois : "L'homme n'a pas une seule et même vie; il en a plusieurs mises bout à bout, et c'est sa misère. » Dans la traduction de Paul Auster, qui met cette citation en épigraphe de son roman : MMan has not one and the same life. He has many lives, place end to end, and that is the cause of his misery."

Après la mort d'Alma, plongé dans un nouveau deuil, Zimmer reprend le travail sur les Mémoires d'Outre-Tombe. 
I put in long hours with the Chateaubriand, rising early and going to bed late, and I made steady progress as the weeks went on, gradually increasing my daily quota from three finished pages of the Pléiade edition to four. It looked like progress, it felt like progress, but that was also the period when I became prone to curious lapses of attention, fits of absentmindedness that seemed to dog me whenever I wandered from my desk. (Auster 314)

Vers la fin du roman, on se met à soupçonner que sa traduction des Mémoires restera à jamais inachevée.

Conformément à l'esprit de l'original, le traducteur français prend soin de rassembler, en appendice au roman, les fragments que «Zimmer » inclut dans sa narration :

La traduction en anglais faite par David Zimmer des Mémoires d'outre-tombe est trop belle pour que les lecteurs français soient privés d'une chance de l'apprécier (Auster-Le Bœuf 366).

Tout à la fin du récit une autre possibilité apparaît au lecteur attentif, une autre parallèle entre le destin de Zimmer et celui d'Hector. Il se peut que la traduction de Zimmer, achevée et intégrale, sera trouvée un jour dans la mémoire de son ordinateur, ou bien dans un tiroir, dans un archive - tout comme les films présumés perdus d'Hector Mann :

They're only missing and sooner or later a person will come along who accidentally opens the door of the room where Alma hid them, and the story will start all over again.

I live with that hope. (Auster 321)

" Je vis dans cet espoir, » écrit Zimmer. Or, au moment où nous lisons la dernière phrase de son récit, nous pouvons "avoir la certitude que l'homme qui l'a écrit est mort depuis longtemps » (Auster-Le Bœuf 361) :

Following Chateaubriand's model, I will make no attempt to publish what I have written now. I have left a letter of instruction for my lawyer, and he will know where to find the manuscript and what to do with it after I am gone. I have every intention of living to a hundred, but on the off chance I don't get that far, all the necessary arrangements have been made. If and when this book is published, dear reader, you can be certain that the man who wrote it is long dead. (ibid. 318)

Au point final de l'histoire de Zimmer, les Mémoires d'Outre-Tombe ne sont plus « un tas de charbon à pelleter » (Auster-Le Bœuf 82), mais un modèle à suivre. Le lecteur ne saura rien sur le destin de la traduction entreprise par Zimmer. I1 
apprendra pourtant que le professeur nous a laissé un manuscrit, un message, et qu'il a nettement exprimé sa volonté de nous parler de l'au-delà. Cette volonté distingue Zimmer d'Hector Mann et le rapproche de son deuxième ange sauveur, le prolifique auteur de la meilleure autobiographie jamais écrite. Hector Mann fait détruire son œuvre; en effaçant ses images, il se condamne à un silence définitif qu'il ne peut plus rompre, qui ne sera probablement jamais rompu, sauf par coïncidence. Chateaubriand et Zimmer, qui s'expriment en paroles, refusent de se taire.

\section{BIBLIOGRAPHIE}

Auster, Paul. The Book of Illusions. London: Faber and Faber, 2002.

Auster, Paul. Le livre des illusions. Traduit par Christine Le Bœuf. Paris: Actes Sud, 2002.

Chateaubriand, François René de. Mémoires d'Outre-Tombe. Paris: Gallimard, Bibliothèque de la Pléiade, 1951.

Memoirs of Chateaubriand: from his birth in 1768 to bis return to France in 1800 . London: Henry Colburn, 1849

The memoirs of François René, vicomte de Chateaubriand. Translated by Alexander Teixeira De Mattos. New York/London: G.P. Putnam/Freemantle, 1902.

Chateaubriand, François René de. Memoirs from beyond the tomb. Selected and translated by Robert Baldick. London: Penguin Books, 1972.

Chateaubriand, François René de. Mémoires d'Outre-Tombe (Memoirs from Beyond the Grave). Translated by A.S. Kline. https://www.poetryintranslation.com, 2005. Chateaubriand, François René de. Mémoirs from Beyond the Grave. Translated by Alex Andriesse. New York: The New York Review of Books, 2018.

Senancour, Étienne Pivert de. Obermann. Paris: Charpentier, 1863.

Barone, Denis. Beyond the Red Notebook : Essays on Paul Auster. Philadeplhia: University of Pennsylvania Press, 1995.

Brown, Mark. Paul Auster. Manchester: Manchester University Press, 2007.

Donovan, Christopher. Postmodern Counternarratives. New York \& London: Routledge, 2005.

Hutchisson, James M., ed.. Conversations with Paul Auster. Jackson: University Press of Mississippi, 2013.

Laufer, Laurie. La sepulture mallarméenne. Pour un tombeau d'Anatole. Cliniques Méditeranéennes 2009/2 (n. 80). Toulouse: ERES, 2009.

Max, D.T.. The Professor of Despair. New York: The Nerw York Times, September 1, 2002 (https://www.nytimes.com/2002/09/01/books/the-professor-of-despair.html). Vervogli, Aliki. The World that is the Book. Liverpool: Liverpool University Press, 2001 
Katarina Marinčič

Université de Ljubljana, Slovénie katarina.marincic@ff.uni-lj.si

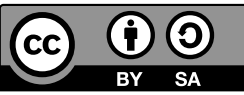

\section{Prevajanje Chateaubrianda v Vermontu: Spomini z onstran groba v romanu Knjiga iluzij Paula Austerja}

Članek obravnava medbesedilne odnose med romanom Knjiga iluzij Paula Austerja ter Spomini z onstran groba Françoisa Renéja de Chateaubrianda. Glavni junak romana se, potem ko je doživel osebno tragedijo, odloči sprejeti velikansko nalogo: v celoti bo prevedel Chateaubriandove Spomine z onstran groba. Delo, ki si ga je naložil, mu sprva služi kot nekakšen začasni motiv za življenje, kot nekaj, s čimer zapolnjuje ure samote in obupa. Vendar pa v nadaljevanju zgodbe monumentalnost Chateaubriandovih spominov kot taka izgubi pomen. Besedilo, ki ga je protagonist-pripovedovalec sprva doživljal kot »kup premoga, ki ga je treba premetati«, postane formalni in moralni vzor. Oglašanje iz onostranstva, kot si ga je zamislil Chateaubriand, se izkaže za pripovedno ogrodje romana in obenem za junakovo moralno vodilo.

Ključne besede: Paul Auster, François René de Chateaubriand, medbesedilnost, prevod, avtobiografija 